\title{
What's at Stake in High-Stakes Testing in Ghana: Implication for Curriculum Implementation in Basic Schools
}

\author{
Isaac Amoako ${ }^{1}$ \\ ${ }^{1}$ Department of Education and Psychology, University of Cape Coast, Ghana \\ Correspondence: Isaac Amoako, University of Cape Coast, Ghana. \\ Email: isaac.amoako2@stu.ucc.edu.gh
}

Received: December 24, $2018 \quad$ Accepted: February 21, $2019 \quad$ Online Published: March 1, 2019

doi: 10.23918/ijsses.v5i3p72

\begin{abstract}
The study sought to investigate perceived effect of BECE, as a high-stakes test on curriculum implementation in Ghana. Twenty (20) Junior High Schools were selected from the total of fifty (50) Junior High Schools within Kwahu South District, Eastern Region of Ghana, for the study. A descriptive crosssectional survey design was used. Proportionate stratified sampling procedure was used to select one hundred and twenty (120) teachers. However, the response rate was $91 \%$ representing 109 teachers. Data were collected using an adapted Teacher's High-Stakes Testing Survey (THTS) questionnaire. Statistical procedures used in data analysis were mainly means and standard deviations. The study discovered that BECE as a high-stakes test that drives curriculum implementation in Ghana, places our "national curriculum" and "teaching practices" at stake. It is recommended that GES as a matter of policy provides appropriate in-service training to JHS teachers on the unintended effect of BECE and the need for teachers to engage in broad curriculum implementation to minimise the effect that accompanies it.
\end{abstract}

Keywords: Curriculum Implementation, High-Stakes Testing, Instruction

\section{Introduction}

In many nations or states around the world, assessing students using a test has metamorphosed from a means of checking students' progress in academic work into a strategy for holding teachers, school administrators, and learners acountable (Shepard, 2000). Demand by political leaders and the general public for good performance in our schools have led to an explosion of testing requirements, that place both teachers and students at a tight corner to ensure that learning is occurring in our schools effectively (Popham, 2003; Hoffman, Assaf, \& Paris, 2001; Barksdale-Ladd \& Thomas, 2000; Paris \& Urdan, 2000).

An educational reform that emphasizes testing, as we are aware today, dates back to the mid-1930s. At the latter part of 1940s, almost all the schools in the United States of America for example, were accustomed to a particular standardized test (Callahan, 1962). In the 1950s cross-checking and making a decision on the kind of education goal(s) to implement within the schools became the order of the day and it was done under the National Defense Education Act (NDEA). The Elementary and Secondary Education Act came to the scene around 1960s to make sure that test scores were used to assess the progress of high-poverty schools. Around 1970s, there was a shift of focus from checking the progress of high-poverty schools to assessing minimum competencies of students using a test. In the 1980's National Assessment of Educational Progress (NAEP) through their report brought an initiative to randomly 
sample test cores of students in a state mandated examination to tell how well schools are performing and to hold schools accountable as well. In the 1990's the concentration drifted to checking the national standard of education, in this case proficiency standard was set to be the benchmark for evaluation of schools, states and districts (Cross, 2004). Finally, the passage of No Child Left Behind (NCLB) Act, several states came up with a standard and accountability policies to cross-check and regulate school systems for better performance (Goldberg, 2004).

In developing countries, especially, those on the African continent, the use of high-stakes tests at the basic level remains an important part of educational reform. For example, assessment in South African schools have been dominated by the Junior Certificate Examinations which is a national exam conducted annually (Lubisi \& Murphy 2002). Describing the impact of this examination (Junior Certificate) to the South Africans, Jansen (2008) indicated that the results have significant and far-reaching implications for students' opportunities after school, in terms of their future career. In Nigeria, a similar high-stakes national examination called Junior Secondary Certificate Examination (JSCE) is also taken after a child goes through nine years of uninterrupted schooling (Gbagolo, 2011). This national examination is critical in determining a child's next academic fortune. The obvious belief that runs through all the above standardised tests are that, they are high-stakes tests and could have an unintended effect on curriculum implementation with particular reference to instruction, scope of the curriculum, stress and satisfaction of the instructor (O’Neill, 2003).

Ghana's Education system has sailed through several important changes since the attainment of our political freedom. In about a decade now, giant strides have been made with respect to improving education access and quality by successive Ghana government and its development partners toward the attainment of Sustainable Development Goal 4 which aimed at ensuring inclusive and equitable quality education and promote lifelong learning opportunities for all. Even though there has been drastic improvement in our education system by means of policy, there exist challenges with respect to students' achievement to be ironed out (Akyeampong, Djangmah, Oduro, Seidu, \& Hunt, 2007). The case of Ghana, with respect to high-stakes testing, is not quite different from countries in both developing and developed world. In Ghana, there are several high-stakes tests that are mostly administered to students at different levels of the educational ladder. For purposes of emphasis, "Basic Education Certificate Examination (BECE) is a high-stakes test at the basic level whereas the West African Senior Certificate Examination (WASSCE) is a high-stakes test at the second cycle level" (Anamuah-Mensah Committee report, 2002, p.28, Anane, 2010). The curious mind would want to find out, what's at stake with the use of BECE as a state mandated test in Ghana? The basic level of education serves as a foundational level critical to a child's academic development. Hence, it is important for empirical study of this nature to be done to ascertain what's at stake with particular reference to the use of BECE as a high-stakes test in Ghana.

Greater responsibility rest on teachers to prepare learners well for a test especially, if the test has stakes on it. Studies have shown that the heightened desire for teachers to overly concentrate on test scores of their students could be disastrous to their professional practice (Darling-Hammond, 2004; Marchant, 2004; Smyth, 2008). First, high-stakes testing could be a license for bad teaching (Barksdale-Ladd \& Thomas 2000). Second, test of high-stakes has been found to aid teachers to narrow the scope of the 
curriculum, which they do by teaching to the test (Madaus \& Clarke, 2001; McNeil, 2000). Third, with respect to teacher job satisfaction, teachers' morale and job satisfaction has been found to decrease due to test accountability pressures (Fullan, 2007). It is therefore obvious that high-stakes testing situation has effects on curriculum, teaching and teacher job satisfaction in different and more developed jurisdictions like US and UK just to mention but a few. However, when it comes to the effects that highstakes BECE has on curriculum implementation in Ghana, much has not been documented. This is because most studies done in Ghana on BECE, focused attention on how teachers' classroom assessment practices affect performance at the end of the BECE (Agbeti, 2014; Hayford, 2007; Konadu, 2015), and also factors affecting low academic performance of students in the BECE (Adane, 2013; Yeboah, 2014). Unattended to are the consequences of this testing situation on curriculum implementation in Ghana. This study therefore sought to investigate the important component of Ghana curriculum implementation at the basic level which is at stake as we continue to use BECE as a gate keeper of our test-based accountability system.

\section{Classical True-Score Theory}

The theory is an illustrative of observed test scores (performance) which is explained by its assumptions. The theory tells how errors of measurement can one way or the other affect learners obtained scores (Allen \& Yen, 1979). The model holds that, if certain assumptions could be considered right, then the outcome of such assumptions could also possibly be right. The basic assumption among other assumptions has to do with the fact that, a person's score on a test (performance) is a composite of two scores; thus "True score (T)" and an "Error score (E)". Mathematically, it is written as X= T+E; where X is the observed score, $\mathrm{T}$ is the theoretical true score and $\mathrm{E}$ is an error score (Allen \& Yen, 1979). In classical true-score theory, the true scores and error scores are assumed to add rather than to have some other relationship, such as a multiplicative one. The most important aspect of this theory is the fact that, the theoretical true score is a stable one upon repeated testing while the error score varies depending on the testing conditions and psychological conditions of testees (Allen \& Yen, 1979).

In the contest of this study, the focus is on the nature of the curriculum being implemented and the teaching practices of the teachers at the basic level. That is to say that if the curriculum being implemented is narrowed by teachers because of the teaching practices that they have adopted (thus teachers teaching to the test), then observed scores of students (X) accrued from a test would be full of errors (E) that would tend to bury the true scores $(\mathrm{T})$ of students on a test. In other words, to increase the theoretical true score of students on a test is to large extent contingent on the nature of the curriculum been implemented by teachers (narrowed or broad) and the teaching practices of teachers. When teachers implement broader curriculum, it helps students to understand issues relating to the concept in a broader perspective however, if the curriculum is narrowed through "teaching to the test" and "selective instruction" where only topics that do often appear on the test are taught then students are more likely to have a distorted idea or understanding about the concept.

\section{Impact of High-Stakes Testing on the Scope of the Curriculum}

Costigan (2002) interviewed six (6) first-year teachers who teach in grade three, four and five. Interview data were taken from respondents for semester one and semester two when teaching sections were 
completed. The study discovered that testing had a negative impact on the scope of the curriculum, thus its narrows scope of the curriculum.

Similarly, Crocco and Costigan (2007) carried out a study to explore teachers work in New York. The study employed a qualitative case study design where newly engaged teachers of less than 5 years' experience were interviewed. In a focus group interview, teachers indicated that they had narrowed the scope of the curriculum being implemented because they had a feeling that they had lost control of the teaching job. Lipman (2004) investigated elementary teachers in Chicago implementation of the elementary school curriculum. Due to the qualitative nature of the study, she observed the teachers from four different schools. The study revealed that teachers' instructional activities in the classroom were that which narrows the scope of the curriculum being implemented. Anane (2010) also investigated the use of senior secondary school certificate examination (SSSCE) results on teachers' instructional method and the curriculum been implemented in schools in Ghana. A descriptive survey design was used. Twenty (20) senior secondary schools were selected from eighty-two (82) senior secondary schools in the Ashanti Region using the simple random technique. In all, three hundred and fourteen (314) questionnaires were distributed. With this, 251 teachers forming approximately $80 \%$ of the number of teachers responded by completing the questionnaires. Out of this, 30.3\% taught Mathematics, 34.7\% Science and $35.0 \%$ English Language. The study found out that the overemphasis on the WAEC examination (SSSCE) gradually shapes the content from broad curriculum to examination-focused teaching (narrowed curriculum). In summary the empirical studies have shown that overemphasis on test scores tend to make teachers narrow the curriculum to reflect test items that do appear on the statewide test.

\section{Impact of High-Stakes Testing on Teaching Practices}

Assaf (2006) conducted a qualitative ethnographic study. In the study he observed a single teacher in a classroom in Texas who was teaching English reading. Amazingly, Assaf saw the instructor varying her teaching from rich and genuine experiences to test-bases teaching which focuses on improving low level test taking skills which matches with Texas statewide test. Again, scholars have reported that tests with stakes do negatively affect classroom teaching (Cankoy \& Tut, 2005; Paris \& Urdan, 2000). A study with an opposing view suggested that high-stakes testing reduces the rate at which teachers become creative while teaching and hence learners do not enjoy the lessons taught because their teachers merely teach to the test (Gardner, 2002). Moreover, it is empirically found that high-stakes tests in most cases measures lower level thinking skills rather than higher level thinking skills (Paris, 2000). Gulek (2003) opined that when the stakes on a test is high, teachers are more likely to focus on the objectives that are tested leaving the rest of the curriculum objectives. Gulek recommended that teachers should not priorities drilling students on a test when covering curriculum objectives. Drilling students on a test as an instructional practice would yield higher scores however, the knowledge base of the students would only be limited to the objectives that the test items covered.

\section{Research Questions}

The following research questions were posed to guide the study:

1. What perception do Junior High School teachers have about the effects of BECE on curriculum? 
2. What is the perception of Junior High School teachers about the effects of BECE on teaching?

\section{Research Methods}

The study made use of a descriptive study design. The target population for the study was junior high school teachers in the Kwahu South District which was made up of 303 teachers of the public Basic Schools in the Kwahu South District. The accessible population was however estimated to be 120 teachers in the selected 20 public junior high schools in the District. The selection of the 20 schools and 120 teachers were carried out in two stages. The first stage involved a proportionate stratified sampling of 20 schools from the 50 schools within the district by the researcher. With this procedure, simple random method was used to select four schools from circuit one, two schools from circuit two, three schools from circuit three, four, six and seven whereas two schools were selected from circuit five. The common ratio for selection of the schools was 4:10 (0.4). On the second stage the researcher used a census approach to involve all the 120 teachers in the study as respondents. The research instrument used for the study was Teachers' High Stakes Testing Survey (THTS) questionnaire developed by Hope, Brockmeier, Lutfi, and Sermon (2006). The six-section questionnaire was adapted and was made up of 42 items on a four-point Likert scale which begins with 1 (strongly disagree) and ends at 4 (strongly agree) across six hypothetical subscales. After the adaptation process the instrument was pilot tested using thirty (30) Junior High School teachers from 3 schools in the Kwahu East District. This was done purposely for the purpose of refining the instrument to improve it reliability and validity. The Cronbach Alpha reliability estimate for the two subscales instrument were "teaching" .89, and curriculum .70. The questionnaire was administered to 120 teachers in the 20 sampled Junior High Schools for the study by the researcher himself. Permission was sought from the head teachers of the various schools who allowed the researcher to administer the questionnaire after an introductory letter had been delivered to them (head teachers) for permission and co-operation. One month was used for the data collection exercise after the respondents have been assured of confidentiality and anonymity. The response rate was $91 \%$. The nine percent $(9 \%)$ was as a result of teacher absenteeism. The two research questions were analyzed using descriptive statistics specifically, mean and standard deviation.

\section{Results}

\subsection{Research Question One}

What perception do Junior High School teachers have about the effects of BECE on curriculum?

This question sought to find out the perception of teachers within the junior high schools in the Kwahu South District concerning the effect that BECE has on the national curriculum. questionnaire was used and the responses analyzed using means and standard deviations with cut-off point values as (1-1.9= strongly disagree, $2.0-2.4=$ disagree, $2.5-3.4=$ agree; more than 3.4 = strongly agree). 
Table 1: Means and Standard Deviations of perceived effect of BECE on the implementation of the national curriculum $(\mathrm{N}=109)$

\begin{tabular}{|c|c|c|}
\hline Statements & Mean & Std. \\
\hline BECE has led me to reassess my beliefs about subject matter that is important to teach. & 3.2 & .82 \\
\hline BECE hardly permit me to give equal attention to all topics. & 2.2 & .97 \\
\hline $\begin{array}{l}\text { Students' scores in BECE accurately reflect quality implementation of the national } \\
\text { curriculum. }\end{array}$ & 2.1 & .93 \\
\hline $\begin{array}{l}\text { To get higher scores in the BECE means that I should solve more past questions with } \\
\text { my students. }\end{array}$ & 3.1 & .81 \\
\hline $\begin{array}{l}\text { BECE test questions accurately reflect the content students learn in the national } \\
\text { curriculum implemented by schools. }\end{array}$ & 2.7 & .97 \\
\hline BECE scores actually reflect restricted range of student knowledge and skills. & 2.8 & .87 \\
\hline BECE questions cover all the curriculum objectives. & 2.1 & 1.0 \\
\hline Mean of Mea & 2.60 & .91 \\
\hline
\end{tabular}

From Table 1, the overall average mean of 2.60 compared to the cut-off point of 2.5-3.4 for agree, indicates that teachers (respondents) believe that Basic Education Certificate Examination (BECE) has effect on the national curriculum been implemented in schools. The average standard deviation score (SD $=.91$ ) also suggest that, teachers' responses to the items on this particular subscale were homogeneous. The teachers reported in agreement $(\mathrm{M}=3.2, \mathrm{SD}=.82)$ that, BECE has made me to recheck my beliefs about the content that is important to teach. This was followed by teachers' agreement $(\mathrm{M}=3.1, \mathrm{SD}=.81)$ that "To get higher scores in the BECE means that I should solve more past questions with my students." Again, teachers further agreed $(\mathrm{M}=2.8, \mathrm{SD}=.87)$ that "BECE scores actually reflect restricted range of student knowledge and skills." To this end students' knowledge does not go beyond the questions they rehearse in the classroom since that was the length and breadth of the syllabus they were exposed to. In support of earlier views on the instrument, teachers agreed $(\mathrm{M}=2.7$, $\mathrm{SD}=.97)$ to the statement, "BECE test questions accurately reflect the content students learn in the national curriculum implemented by schools." To the respondents, BECE test items in most cases do not cover the entire curriculum objectives. This situation might cause most teachers to narrow the curriculum to those objectives that are being tested leaving equally important objectives unattended to.

\subsection{Research Question Two}

What is the perception of Junior High School teachers about the effect of BECE on teaching?

This research question was used to find out junior high school within the Kwahu South District perception about the effect of BECE on teaching practices. Questionnaire was used and the data analysed using means and standard deviations with cut-point values as (1-1.9 = strongly disagree, $2.0-2.4=$ disagree, 2.5-3.4 = agree; more than 3.4 = strongly agree). 
Table 2: Means and Standard Deviations of the perceived effect of BECE on Teaching Practices

\begin{tabular}{lccc}
\hline Statements & Mean & Std. \\
\hline BECE does not permits me to use the full range of my teaching skills. & 2.4 & .93 \\
BECE does provide enough room (e.g. in terms of time) for me to teach & 2.1 & .99 \\
better. & & \\
Students' scores in BECE are a valid measure of teaching ability. & 1.9 & .91 \\
My attention on BECE result increases my creativity in the classroom. & 2.2 & .92 \\
The quality of my teaching is directly related to student performance in the & 2.7 & 1.1 \\
BECE. & & \\
BECE require test preparation that reduces time to teach other topical & 2.9 & .94 \\
content. & & \\
Students' scores in BECE provides me with information to improve my & 3.4 & .70 \\
teaching. & & \\
Effective teaching and learning is about students getting high scores at the & 2.5 & 1.2 \\
end of the BECE. & & \\
BECE motivates me to engage in student-centered mode of instruction. & 3.1 & .78 \\
BECE had made me to encourage my students to memorize factual concept. & 2.9 & .86 \\
\hline & & \\
\hline
\end{tabular}

From Table 2, the overall average mean of 2.61 compared to the cut-off point mean score of 2.5-3.4= agree, indicates that respondents share the opinion that BECE has effect on the teaching practices of junior high school teachers. The average standard deviation score $(\mathrm{SD}=.93)$ also suggests that, the responses of the respondents were in a uniform fashion. The responses reflect intended and unintended effects of BECE. First, teachers agreed $(\mathrm{M}=3.4, \mathrm{SD}=.70)$ that students' scores in BECE provide them with information to improve their teaching. This was followed by their agreement $(\mathrm{M}=3.1, \mathrm{SD}=.78)$ that BECE motivate them to engage in student centered mode of instruction. In telling details of their engagement with students, teachers agreed $(\mathrm{M}=2.9, \mathrm{SD}=.86)$ that BECE has made them to encourage students to memorise factual concept (rote learning). Again, teachers concerted $(\mathrm{M}=2.9, \mathrm{SD}=.94)$ to the fact that BECE has made them to spend much time in preparing students for test, leaving other detail topical content areas untouched especially, those that do not often appear on the test.

\section{Discussion}

Research question one sought to investigate BECE unintended effect on the scope of the national curriculum being implemented. From the data analysis, results indicate that teachers (respondents) believe that BECE has effect on the scope of the national curriculum being implemented in Ghana. In 
other words, teachers reported to have engaged students in a narrowed curriculum because of the accountability pressure attached to BECE. For purposes of emphasis, teachers reported to have taught content areas that do frequently appear in the BECE. Again, most teachers reported to have spent much of their time with students covering curriculum objectives on which most often BECE test items are directed. Furthermore, teachers were of the view that BECE results or scores actually reflects restricted range of students' knowledge and skills after completion of basic school in Ghana. This actually presupposes that respondents believe that BECE as a high-stakes test, narrows the national curriculum being implemented in Ghana. The results corroborate several findings as reviewed in the literature that high-stakes testing (BECE in the case of Ghana) can narrow the scope of the curriculum. First, studies have shown that test based accountability can lead teachers to implement a narrowed curriculum whereby teachers drill their students on a test with less regard to other important content of the curriculum (Grant, 2004; Marchant, 2004). Again, in an empirical study, Marchant (2004) asserted that in a high-stakes testing environment, teachers mainly focus on objectives of the curriculum that do appear on a test frequently. In the sense whereby teachers are focusing on an aspect of the curriculum that seems to appear on the BECE test frequently, leaving the rest that do not appear on the test frequently, unarguably suggest that the national curriculum is been narrowed.

There cannot be effective implementation of educational curriculum without efficient teaching practices. For this purpose, research question two sought to find out the perception of Junior High School teachers about the effects of BECE on teaching practices. Respondents reported that BECE does affect their daily teaching of the curriculum content. The responses of the respondents clearly show unintended consequences of BECE on teaching practices. That is to say that BECE has made them to engage in test preparation sort of instruction which focus on topics that do mostly appear on the test. According to respondents, they engage students in learning test taking skills even more which reduces instructional time. Respondents further reported that, instead of engaging students in depth-oriented form of instruction, BECE has made them to encourage students through their teaching to practice rote learning. In other words, teachers reported that BECE has made them to adopt a style of teaching that encourages memorisation of factual concept. The result of this current study support that of Vogler, et al. (2002) who discovered that teachers had altered the way they teach by focusing on objectives that do appear on Massachusetts Comprehensive Assessment System (MCAS) state test. Moreover, Hoffman, Assaf, and Paris (2001) also explored teacher classroom engagement toward state mandated test. In this particular study the emphasis was on how teachers engage their students in class. The findings indicate that tests with stakes significantly reduces quality instructional time to rote memorization of subject content.

\section{Conclusion}

It is evident from the study that, on the whole, BECE as a high-stakes test at the basic level of education in Ghana appears to have an unintended effect on the national curriculum at the implementation level. Most definitely, this situation has implication for quality teaching and learning in the Junior High School. This might lead to shallow teaching on the part of the teachers instead of broader curriculum implementation. On the whole, teachers have squeezed or narrowed the national curriculum. The alarming aspect of this situation is that it is most likely that creativity, opportunity for self-enhanced learning are likely to not to be seen in our classrooms due to the narrowed nature of the scope of our curriculum by teachers to meet external targets (i.e. high scores). This is to say that; the creative higher 
order thinking skills of our students would be missing and hence students that graduate from the Junior High Schools might be able to rationally think through issues as expected and this might affect subsequent studies as they climb the academic ladder.

The pedagogy of teachers dictates the scope of the curriculum that is being implemented (i.e. broad or narrowed). Teachers reported that they "teach to the test". Respondents indicated that their ability to choose appropriate instructional strategy was hinded by the need to prepare students for tests rather than focusing on individual students learning needs. The most alarming aspect of teachers changing their pedagogy to suit the testing situation is that, it undermines the validity of large-scale assessment results in the sense that test results do not represent quality of teaching and Learning and hence the test (i.e. BECE) becomes a misguided tool. In summary, it can be concluded that the use of BECE as a highstakes test that drives curriculum implementation in Ghana, places our "national curriculum" and "teaching practices" at stake.

\section{Recommendation}

1. Head teachers and circuit supervisors should pay particular attention to their supervisory role and ensure that teachers implement broader curriculum and not a narrowed curriculum as shown by the survey.

2. Academicians, expert and researchers in the field of educational measurement and evaluation must play active role in engaging stakeholders on issues relating to testing. The public must be educated on the fact that the proliferated standardized tests in the educational system does not necessarily indicate how much a student knows and can do. Hence, until high-stakes testing is seen as a small portion of a student's educational life, they will continue to cause multiple negative effects.

\section{References}

Agbeti, A. (2014). How external assessment mediates teaching, learning and assessment in Junior high school in Ghana. International Journal of Humanities, Social Sciences and Education, 1(12), $115-125$.

Akyeampong K, Djangmah J., Oduro A., Seidu A., \& Hunt, F. (2007) Access to basic education in Ghana: The Evidence and the Issues - Country Analytic Report: CREATE, University of Sussex.

Anamuah-Mensah Committee Report (2002). Meeting the challenges of Education in the Twenty First Century, Review report of the President's Committee on Education Reforms in Ghana: Author.

Anane, E. (2010). Effects of high-stakes testing on instruction in senior high school. International. Journal of Research in Education, 2(1) 58-66.

Assaf, L. C. (2005). Exploring identities in reading specialization program. Journal of Literacy Research, 37, 201-236.

Barksdale-Ladd, M. A., \& Thomas, K., F. (2000). What's at stakes in high-stakes testing: Teachers and parents speak out. Journal of Teacher Education, 51(5), 384-397.

Callahan, R. (1962). Education and the cult of efficiency. Chicago: University of Chicago Press.

Cankoy, O., \& Tut, M. (2005). High-stakes testing and mathematics performance of fourth graders in north Cyprus. Journal of Educational Research, 98(4), 234- 243. 
Crocco, M. S., \& Costigan, A. T. (2007). The narrowing of curriculum and pedagogy in the age of accountability. Urban Education, 42(6), 512-535.

Cross, C. T. (2004). Political education: National policy comes of age. New York: Teachers College.

Darling-Hammond, L. (2004). Standards, accountability, and school reform. Teachers College Record, 106(6), 1047-1085.

Fullan, M. (2007). Change the terms for teacher learning. National Staff Development, 28(3), 35-36.

Gardner, S. (2002). Forecasting and managing student achievement on high-stakes tests. The Journal, 29(6), 40-41.

Gbagolo, H. (2011). Examination malpractices in Nigeria: A review of literature. Continental Journal of Educational Research, 4(3), 34-43.

Goldberg, M. F. (2004). The high-stakes test mess. Education digest: Essential readings Condensed for Quick Review, 69, 8-15.

Grant, S. (2004). Oppression, privilege, and high-stakes testing. Multicultural Perspectives, 6(1), 3-11.

Gulek C. (2003). Preparing for high-stakes testing. Theory into Practice, 42(1), 42-50.

Hayford (2007). Continuous assessment and lower attaining pupils in primary and junior high school in Ghana. Unpublished doctoral thesis, School of Education, University of Birmingham.

Hoffman, J. V., Assaf, L. C., \& Paris, S. G. (2001). High-stakes testing in reading: Today in Texas, tomorrow? The Reading Teacher, 54(5), 482-492.

Hope, W. C., Brockmeier, L. L., Lutfi, G. A., \& Sermon, J. M. (2006, November). High stakes test's influence on teachers' beliefs. Paper presented at the annual meeting of the Florida Educational Research Association, Jacksonville, FL.

Jansen, J. (2008, Dec. 18). South Africa's experience of large-scale assessment. The Times (No. 132) p.4.

Konadu, K. (2015). Assessment of teaching and learning in basic schools. Unpublished masters of thesis, Department of Development Planning and Management, Kwame Nkrumah University of Science and Technology.

Lipman, P. (2004). High stakes education: Inequality, globalization, and urban school reform. New York: Routledge Palmer.

Lubisi, R.C., and Murphy, R.J.L. (2002). Assessment in South African schools. assessment in national center for research on evaluation, standards, and student testing (CRESST). Boulder: University of Colorado.

Madaus, G. F., \& Clarke, M. (2001). The adverse impact of high stakes testing on minority students: Evidence from 100 years of test data. In G. Orfield \& M. Kornhaber (Eds.), Raising standards or raising barriers? Inequality and high stakes testing in public education (pp. 85-106). New York, NY: Century Foundation.

Marchant, G. (2004). What is at stake with high stakes testing? A discussion of issues and research. Ohio Journal of Science. 104(2), 2-7.

McNeil, L. M. (2000). Contradictions of school reform: Education costs of standardized testing. New York: Routledge.

O’Neill, P. (2003). High stakes testing law and litigation. Brigham Young University Education and Law Journal, 2, 623-662.

Paris, S.G., \& Urdan, T. (2000). Policies and practices of high-stakes testing that influence teachers and schools. Issues in Education 6(2), 83-108.

Popham, J. (2003). Test better, teach better: The instructional role of assessment. Alexandria, VA: Association for Supervision and Curriculum Development.

Shepard, L. A. (2000). The role of assessment in a learning culture, Educational Researcher, 29(7), 414.

Smyth, T. (2008). Who is No Child Left Behind leaving behind? Clearing House, 81(3), 133-137

Vogler, K., Novick, B., Kress, J., \& Elias, M. J. (2002). The impact of high-stakes, state mandated student performance assessment on teacher's instructional practices. Education, 123(1), 39-55. 
International Journal of Social Sciences \& Educational Studies ISSN 2520-0968 (Online), ISSN 2409-1294 (Print), March 2019, Vol.5, No.3

Yeboah, Y. K. (2014). Investigating the low performance of students' in English in the BECE in the Sunyani municipality. Unpublished thesis, University of Ghana. 